\title{
Purification and characterization of a dual function 3-dehydroquinate dehydratase from Amycolatopsis methanolica
}

\author{
G. J. W. Euverink, ${ }^{1}$ G. I. Hessels, ${ }^{1}$ J. W. VRijbloed,${ }^{1}$ J. R. Coggins ${ }^{2}$ and L. Dijkhuizen ${ }^{1 *}$ \\ ${ }^{1}$ Department of Microbiology, University of Groningen, Kerklaan 30, 9751 NN Haren, The Netherlands \\ ${ }^{2}$ Department of Biochemistry, University of Glasgow, Glasgow G12 8QQ, UK
}

(Received 27 May 1992; revised 13 July 1992; accepted 20 July 1992)

\begin{abstract}
Studies on hydroaromatic metabolism in the actinomycete Amycolatopsis methanolica revealed that the organism grows rapidly on quinate (but not on shikimate) as sole carbon- and energy source. Quinate is initially converted into the shikimate pathway intermediate 3-dehydroquinate by an inducible $\mathrm{NAD}^{+}$-dependent quinate/shikimate dehydrogenase. 3-Dehydroquinate dehydratase subsequently converts 3-dehydroquinate into 3-dehydroshikimate, which is used partly for the biosynthesis of aromatic amino acids, and is partly catabolized via protocatechuate and the $\beta$-ketoadipate pathway. Enzyme studies and analysis of mutants clearly showed that the single 3dehydroquinate dehydratase present in $A$. methanolica has a dual function, the first example of a 3-dehydroquinate dehydratase enzyme involved in both the catabolism of quinate and the biosynthesis of aromatic amino acids. This enzyme was purified over 1700-fold to homogeneity. Its further characterization indicated that it is a Type II 3dehydroquinate dehydratase, a thermostable enzyme with a large oligomeric structure (native $M_{\mathrm{r}} 135 \times 10^{3}$ ) and a subunit $M_{\mathrm{r}}$ of $12 \times 10^{3}$. Characterization of aromatic amino acid auxotrophic mutants of $A$. methanolica suggested that genes encoding 3-dehydroquinate synthase and 3-dehydroquinate dehydratase are genetically linked but their transcription results in the synthesis of two separate proteins.
\end{abstract}

\section{Introduction}

Quinate is utilized as a growth substrate by fungi as well as by bacteria and is metabolized via 3-dehydroquinate and 3-dehydroshikimate. These compounds are also intermediates in the shikimate pathway for the biosynthesis of aromatic amino acids (Fig. 1).

In organisms able to grow on both quinate and shikimate the initial step in the metabolism of both substrates generally appears to be catalysed by one and the same enzyme (Giles et al., 1985). In Gram-negative bacteria this enzyme was characterized as a pyrroloquinoline quinone (PQQ)-dependent quinate dehydrogenase (van Kleef \& Duine, 1988) while Gram-positive bacteria (including nocardioform actinomycetes) and fungi employ an $\mathrm{NAD}^{+}$-dependent quinate dehydrogenase (Bruce \& Cain, 1990; Cain, 1972b, 1981). Neurospora crassa and several species of rhodococci are able to grow on quinate but not on shikimate, probably because in these

\footnotetext{
* Author for correspondence. Tel. 50 632153; fax 50632154.
}

Abbreviations: DAHP, 3-deoxy-D-arabino-heptulosonate 7-phosphate; $\mathrm{PQQ}$, pyrroloquinoline quinone. organisms shikimate is not an inducer of the quinate/shikimate dehydrogenase (Cain, 1981; Chaleff, 1974).

The dehydration of 3-dehydroquinate to 3-dehydroshikimate is catalysed by two different types of dehydroquinate dehydratase, distinguishable on the basis of enzymological and biophysical properties (Kleanthous $e t$ al., 1992). The Type I enzymes characterized thus far have a solely biosynthetic function in the shikimate pathway and are expressed constitutively. A representative example is the Escherichia coli enzyme, a dimeric (subunit $M_{\mathrm{r}} 29 \times 10^{3}$ ) and heat-labile protein (Chaudhuri et al., 1986). In Aspergillus nidulans and $N$. crassa the Type I enzyme is part of a pentafunctional complex of shikimate pathway enzymes (AROM complex) (Lumsden \& Coggins, 1977; Charles et al., 1985). During growth on quinate these organisms employ an additional Type II enzyme, an inducible, dodecameric (subunit $M_{\mathrm{r}}$ $18 \times 10^{3}$ ) and heat-stable protein (Giles et al., 1967, 1985; Cain, 1972a; Lamb et al., 1990; Kleanthous et al., 1992). Recently, it has become clear that Type II enzymes may also function as biosynthetic enzymes in the shikimate pathway of Streptomyces coelicolor (White et al., 1990) and Mycobacterium tuberculosis (Garbe et al., 1991), organisms unable to grow on quinate. Many nocardioform actinomycetes are able to grow on quinate 


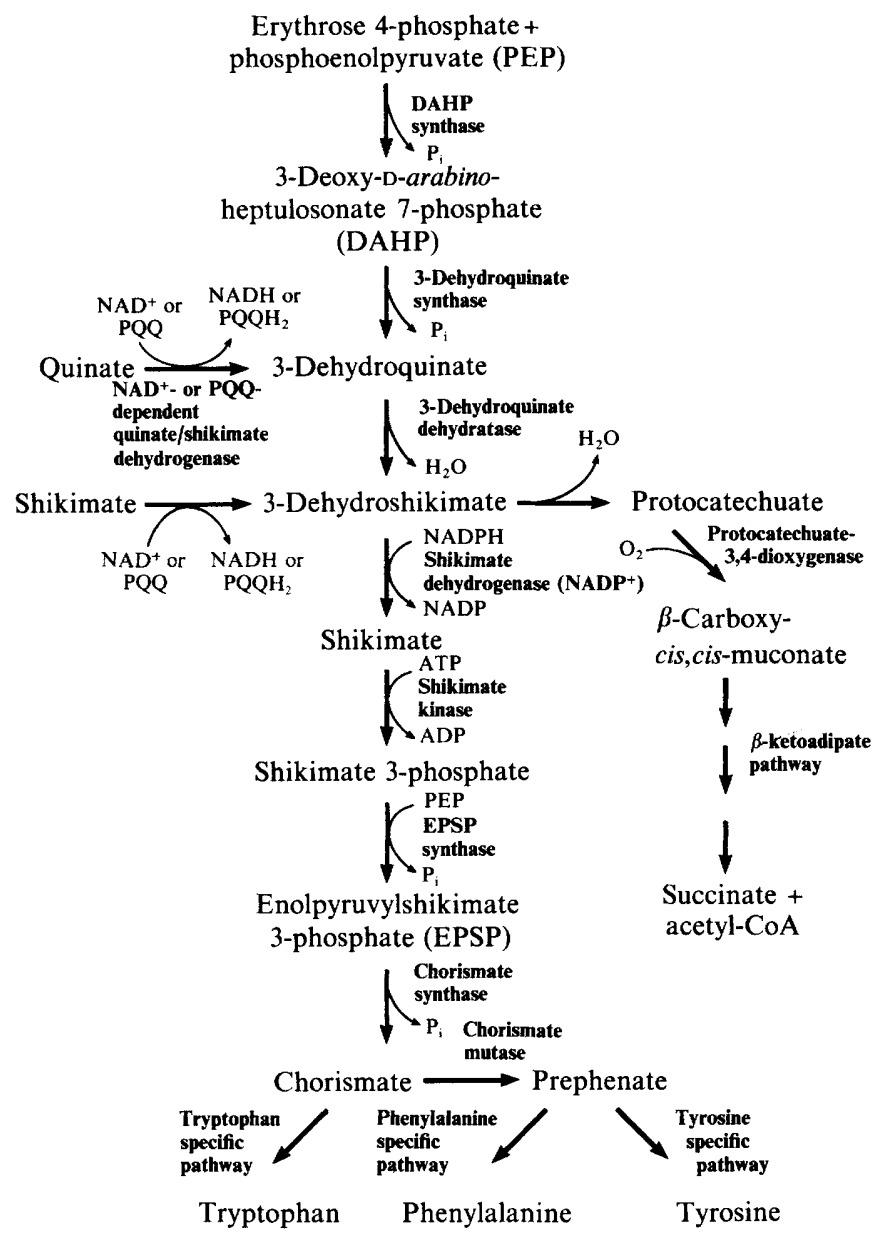

Fig. 1. Schematic representation of the biosynthesis of aromatic amino acids via the shikimate pathway and the catabolism of quinate and shikimate.

and studies on cell-free extracts indicated that these organisms may employ a single Type II dehydroquinate dehydratase with a dual function in quinate catabolism and in the shikimate pathway (Cain, 1981).

We are currently engaged in an analysis of the enzymology and regulation of the shikimate pathway enzymes in the methanol-utilizing actinomycete Amycolatopsis methanolica (previously known as Nocardia sp. 239) (de Boer et al., 1990). Recently, Grund et al. (1990) reported that various Amycolatopsis species are able to use quinate as a carbon- and energy source. Quinate turned out to be an excellent growth substrate for $\boldsymbol{A}$. methanolica as well. In this paper we report an analysis of quinate catabolism and the purification and characterization of a Type II 3-dehydroquinate dehydratase with a dual function in $A$. methanolica. Quinate catabolism can seriously interfere with attempts to overproduce aromatic amino acids via the shikimate pathway (Lamb et al., 1991, 1992). The results allow a clear identification of targets for mutational inactivation of quinate catabolism.

\section{Methods}

Micro-organisms and cultivation. Amycolatopsis methanolica NCIB 11946, its maintenance and the procedures for cultivation in batch cultures have been described previously (de Boer et al., 1989). Glucose was heat-sterilized, quinate and shikimate were filter-sterilized, and all three were added to final concentrations of $10 \mathrm{~mm}$. A plasmid-cured derivative, strain WV2 ( $\mathrm{J}$. W. Vrijbloed, unpublished) was used in all experiments.

Respiration studies with whole cells. Cells from the mid-exponential phase of growth were harvested by centrifugation at $6000 \mathrm{~g}$ for $10 \mathrm{~min}$ at room temperature, washed five times with mineral medium and resuspended in mineral medium. Respiration rates were determined with a polarographic oxygen probe at $37^{\circ} \mathrm{C}$. The reaction was started by addition of substrate to a final concentration of $10 \mathrm{mM}$. Protocatechuate was added to a final concentration of $2.5 \mathrm{~mm}$. The specific respiration rate was expressed as $\mathrm{nmol} \mathrm{O}_{2} \min ^{-1}$ (mg protein) $)^{-1}$.

Mutant isolation. Auxotrophic mutants blocked in the shikimate pathway were isolated using the diepoxyoctane treatment as previously described (de Boer et al., 1988). In the screening procedure glucose mineral medium was supplemented with aromatic amino acids, each to a final concentration of $1 \mathrm{mg} \mathrm{l}^{-1}$. Pinpoint colonies were selected for further characterization.

Shikimate-utilizing spontaneous mutants of strain WV2 were 
isolated in liquid mineral medium cultures with shikimate as sole carbon- and energy source. Growth was observed after incubation for approximately a week on a rotary shaker at $37^{\circ} \mathrm{C}$. After plating on shikimate agar, single mutants were isolated and characterized.

Extract preparation and enzyme assays. Cells from the midexponential phase of growth were harvested by centrifugation at $6000 \mathrm{~g}$ for $10 \mathrm{~min}$ at $4{ }^{\circ} \mathrm{C}$, washed five times in $50 \mathrm{mM}$-Tris $/ \mathrm{HCl}$, $\mathrm{pH} 7 \cdot 5$, and resuspended in the same buffer. Cells were disrupted in a French pressure cell at $1000 \mathrm{MPa}$. Unbroken cells and debris were removed by centrifugation at $40000 \mathrm{~g}$ for $30 \mathrm{~min}$ at $4{ }^{\circ} \mathrm{C}$. The supernatant, containing $2.5-5.0 \mathrm{mg}$ protein $\mathrm{ml}^{-1}$, was used for enzyme assays at $37^{\circ} \mathrm{C}$.

Quinate dehydrogenase and shikimate dehydrogenase $\left(\mathrm{NAD}^{+}\right.$ dependent; EC 1.1.1.24) were assayed according to Bruce \& Cain (1990).

3-Dehydroquinate synthase (EC 4.6.1.3) activity was assayed using the $E$. coli 3-dehydroquinate dehydratase and NADP ${ }^{+}$-dependent shikimate dehydrogenase as coupling enzymes and monitoring the oxidation of NADPH at $340 \mathrm{~nm}$. The assay mixture contained $50 \mathrm{mM}-$ Tris/ $\mathrm{HCl}, \mathrm{pH} 8.5,1 \mathrm{~mm}-\mathrm{CoCl}_{2}, 0.25 \mathrm{~mm}-\mathrm{NAD}^{+}, 0.05 \mathrm{~mm}-\mathrm{NADPH}$, 0.2 U 3-dehydroquinate dehydratase (Chaudhuri et al., 1987b), $0.2 \mathrm{U}$ $\mathrm{NADP}^{+}$-dependent shikimate dehydrogenase (Chaudhuri et al., 1987a), 0.02 mM-3-deoxy-D-arabino-heptulosonate 7-phosphate (DAHP) and extract in a total volume of $1.0 \mathrm{ml}$.

3-Dehydroquinate dehydratase (EC 4.2.1.10) activity was assayed according to White et al. (1990) at $\mathrm{pH} 8.5$.

Shikimate: $\mathrm{NADP}^{+}$3-oxidoreductase $\left(\mathrm{NADP}^{+}\right.$-dependent shikimate dehydrogenase) (EC 1.1.1.25) was assayed in the reverse direction by monitoring the oxidation of NADPH at $340 \mathrm{~nm}$. The assay mixture contained $50 \mathrm{mM}$-Tris $/ \mathrm{HCl} \mathrm{pH} \mathrm{8.5,2} \mathrm{mM-shikimate,} 0.15 \mathrm{~mm}$ NADPH and extract in a total volume of $1.0 \mathrm{ml}$.

3-Dehydroshikimate dehydratase (EC 4.2.1.?) was assayed by following the formation of protocatechuate at $290 \mathrm{~nm}$ (molar extinction coefficient $3.89 \times 10^{3} \mathrm{M} \mathrm{cm}^{-1}$ ) (Bruce \& Cain, 1990; Strøman et al., 1978 ) or the disappearance of 3-dehydroshikimate at $234 \mathrm{~nm}$ (molar extinction coefficient $\left.12 \times 10^{3} \mathrm{M} \mathrm{cm}^{-1}\right)$.

Protocatechuate-3,4-dioxygenase (EC 1.13.11.3) was assayed by monitoring the consumption of oxygen with a polarographic oxygen probe. The assay mixture contained $50 \mathrm{~mm}$-Tris/ $\mathrm{HCl}, \mathrm{pH} 7.5,2.5 \mathrm{~mm}-$ protocatechuate and extract in a total volume of $3.0 \mathrm{ml}$.

$\mathrm{NAD}^{+}$-dependent shikimate- and quinate dehydrogenase were visualized after gel electrophoresis under non-denaturating conditions by quinate- or shikimate-dependent tetrazolium activity staining. Crude extracts of quinate-grown cells were loaded on a $7 \%(w / v)$ polyacrylamide gel in $100 \mathrm{mM}$-glycine/Tris, $\mathrm{pH}$ 9.0. After electrophoresis $\left(100 \mathrm{~V}\right.$, constant current, $\left.4^{\circ} \mathrm{C}\right)$, the gels were stained in staining buffer, containing $60 \mathrm{mg} \mathrm{NAD}+, 1 \mathrm{mg}$ phenazine methosulphate (PMS), $15 \mathrm{mg}$ 3-(4,5-dimethyl-2-thiazolyl)-2,5-diphenyl-2H-tetrazolium bromide (MTT) and $60 \mathrm{mg}$ shikimate or quinate in atal volume of $30 \mathrm{ml}$. The gel was incubated in the assay mixture at $37^{\circ} \mathrm{C}$ in the dark.

Partial purification of dehydroquinate synthase, dehydroquinate dehydratase, $N A D P^{+}$-dependent shikimate dehydrogenase, $N A D^{+}$-dependent shikimate dehydrogenase and $N A D^{+}$-dependent quinate dehydrogenase. Crude extracts from either glucose-grown cells or quinate-grown cells of $\boldsymbol{A}$. methanolica strain WV2 were applied on a Mono Q HR 5/5 anionexchange column. Bound protein was eluted with an increasing linear gradient of $0-0.5 \mathrm{M}-\mathrm{NaCl}$ in $50 \mathrm{~mm}-\mathrm{Tris} / \mathrm{HCl}, \mathrm{pH} 7.5$. Fractions of $0.5 \mathrm{ml}$ were collected.

Purification of 3-dehydroquinate dehydratase

Enzyme purification was done at room temperature unless stated otherwise. Centrifugation steps were done at $4^{\circ} \mathrm{C}$. All chromatographic steps were carried out with a System Prep 10 liquid-chromatography system (Pharmacia LKB).
Step 1. Glucose-grown cells were harvested in the stationary phase $(82 \mathrm{~g}$ wet weight). Cell-free extract was prepared as described above. DNAase and $1 \mathrm{~mm}-\mathrm{MgCl}_{2}$ were added to the cell-free extract, which was then incubated for $10 \mathrm{~min}$.

Step 2. Ammonium sulphate precipitation. Solid $\left(\mathrm{NH}_{4}\right)_{2} \mathrm{SO}_{4}$ was added slowly to the cell-free extract $(194 \mathrm{ml}$; step 1) to a final concentration of $40 \%$ saturation $(43.84 \mathrm{~g})$. The mixture was stirred for $30 \mathrm{~min}$ at $4{ }^{\circ} \mathrm{C}$ and centrifuged for $30 \mathrm{~min}$ at $40000 \mathrm{~g}$. The supernatant $(208 \mathrm{ml})$ was decanted and slowly adjusted to $60 \%$ saturation $\left(\mathrm{NH}_{4}\right)_{2} \mathrm{SO}_{4}(24.96 \mathrm{~g})$. The mixture was stirred for $30 \mathrm{~min}$ at $4{ }^{\circ} \mathrm{C}$ and centrifuged for $30 \mathrm{~min}$ at $40000 \mathrm{~g}$. The supernatant was discarded and the pellet was dissolved in $45 \mathrm{ml} 50 \mathrm{~mm}$-Tris/ $\mathrm{HCl}, \mathrm{pH} 7.5$ (buffer A), and dialysed overnight against 51 buffer $A$ at $4{ }^{\circ} \mathrm{C}$.

Step 3. The dialysed fraction from step 2 was incubated for $10 \mathrm{~min}$ at $70{ }^{\circ} \mathrm{C}$. Precipitated protein was removed by centrifugation for $30 \mathrm{~min}$ at $40000 \mathrm{~g}$. The pellet was washed in buffer $A$ and centrifuged for another $30 \mathrm{~min}$ at $40000 \mathrm{~g}$ at $4{ }^{\circ} \mathrm{C}$. The two supernatants were combined $(93 \mathrm{ml})$.

Step 4. Two portions of the heat-treated material $(46.5 \mathrm{ml})$ were applied onto a column of Q-Sepharose fast-flow (HR 10/10, bed volume $8 \mathrm{ml}$ ) equilibrated in buffer A. Bound protein was eluted with a twostep increasing linear gradient $(0-0.25 \mathrm{M}-\mathrm{NaCl}$ in $30 \mathrm{ml}$ and $0.25-0.5 \mathrm{M}$ $\mathrm{NaCl}$ in $100 \mathrm{ml}$ ) at a flow rate of $1.0 \mathrm{ml} \mathrm{min}^{-1}$; fractions of $3.0 \mathrm{ml}$ were collected. Peak fractions from both separate steps were pooled and dialysed against 51 buffer $A$. This sample was concentrated on the same Q-Sepharose fast-flow column and eluted with an increasing linear gradient from $0-0.5 \mathrm{M}-\mathrm{NaCl}$ at a flow rate of $2.0 \mathrm{ml} \mathrm{min}^{-1}$ in $240 \mathrm{ml}$. Fractions of $3.0 \mathrm{ml}$ were collected and peak fractions were pooled $(49 \mathrm{ml})$ and dialysed against 51 buffer $\mathrm{A}$.

Step 5. Two portions of protein from step 4 were applied onto a Mono Q HR 5/5 anion-exchange column equilibrated in $50 \mathrm{~mm}-\mathrm{Tris} / \mathrm{HCl}$, pH 8.5 (buffer B). Bound protein was eluted with an increasing linear gradient from $0-0.5 \mathrm{M}-\mathrm{K}_{2} \mathrm{HPO}_{4}$ in $60 \mathrm{ml}$ at $1.0 \mathrm{ml} \mathrm{min}{ }^{-1}$. Fractions of $1.0 \mathrm{ml}$ were collected and peak fractions from these steps were pooled $(19.0 \mathrm{ml})$.

Step 6. Protein from step 5 was adjusted to $1.0 \mathrm{M}-\left(\mathrm{NH}_{4}\right)_{2} \mathrm{SO}_{4}$ and applied onto a phenyl-Superose HR $5 / 5$ hydrophobic-interaction column equilibrated in buffer $\mathrm{B}$ with $1.0 \mathrm{M}-\left(\mathrm{NH}_{4}\right)_{2} \mathrm{SO}_{4}$. Bound protein was eluted with a decreasing linear gradient from $1.0-0 \mathrm{M}-\left(\mathrm{NH}_{4}\right)_{2} \mathrm{SO}_{4}$ in $45 \mathrm{ml}$ at $0.5 \mathrm{ml} \mathrm{min}-1$. Fractions of $1.0 \mathrm{ml}$ were collected and peak fractions were pooled $(6.5 \mathrm{ml})$.

Step 7. Protein from step 6 was incubated for $10 \mathrm{~min}$ at $70^{\circ} \mathrm{C}$ Precipitated protein was pelleted in an Eppendorf centrifuge for $10 \mathrm{~min}$.

Step 8. Protein from step 7 was concentrated to $200 \mu$ in an Amicon ultrafiltration device (cut-off: $M_{\mathrm{r}}$ 10000) and applied onto a Superose 12 HR $10 / 30$ column equilibrated in buffer B. Protein was eluted at a flow rate of $0.5 \mathrm{ml} \mathrm{min}^{-1}$. Fractions of $0.25 \mathrm{ml}$ were collected and peak fractions were pooled $(3.8 \mathrm{ml})$.

Step 9. Protein from step 8 was applied onto a Mono Q HR 5/5 anionexchange column equilibrated in buffer $\mathbf{B}$. Bound protein was eluted with an increasing linear gradient from $0-0.5 \mathrm{M}-\mathrm{NaCl}$ at a flow rate of $0.5 \mathrm{ml} \mathrm{min}{ }^{-1}$ in $30 \mathrm{ml}$. Fractions of $0.5 \mathrm{ml}$ were collected. Fractions were pooled and glycerol was added to a final concentration of $20 \%$ $(\mathrm{v} / \mathrm{v})$ before storing at $-20^{\circ} \mathrm{C}$.

$S D S-P A G E$. This was done according to Laemmli \& Favre (1973) with the following marker proteins: phosphorylase $\mathrm{A}\left(M_{\mathrm{r}} 94 \times 10^{3}\right)$, human transferrin $\left(80 \times 10^{3}\right)$, albumin $\left(68 \times 10^{3}\right)$, catalase $\left(58 \times 10^{3}\right)$, fumarase $\left(50 \times 10^{3}\right)$, citrate synthase $\left(46 \times 10^{3}\right)$, carbonic anhydrase $\left(31 \times 10^{3}\right)$ and ribonuclease $A\left(16 \times 10^{3}\right)$. Gels were stained with Coomassie brilliant blue R250.

Estimation of molecular mass. The $M_{\mathrm{r}}$ of the native enzyme was estimated using a Superose $12 \mathrm{HR} 10 / 30$ column with thyroglobulin $\left(M_{\mathrm{r}}\right.$ $\left.670 \times 10^{3}\right)$, gamma globulin $\left(158 \times 10^{3}\right)$, ovalbumin $\left(44 \times 10^{3}\right)$, 
myoglobin $\left(17 \times 10^{3}\right)$ and cobalamin $\left(1.35 \times 10^{3}\right)$ as gel-filtration standards (Bio-Rad).

Automatic amino acid sequence determination. In two separate experiments the purified protein was transferred by electroblotting to Problot membranes (Matsudaira, 1987) and Amido-Black-stained dehydroquinate dehydratase bands were sequenced by Dr M. Cusack (Department of Pure and Applied Geology, University of Glasgow, UK) and Mr B. Dunbar (Department of Molecular and Cell Biology, University of Aberdeen, UK) on Applied Biosystems model 470A/120A automated gas-phase sequencers equipped with on-line HPLC for detection of the phenylthiohydantoin amino acid derivatives.

Kinetic studies with 3-dehydroquinate dehydratase. Kinetic parameters were determined at $37^{\circ} \mathrm{C}$ and $\mathrm{pH} 8.5$ or $\mathrm{pH} 7.5$. The kinetic parameters were determined with the Enzfitter program (Elsevier software) using a direct fit.

Protein determination. Protein in crude extracts was determined with the Bio-Rad protein determination kit, using bovine serum albumin as a standard (Bradford, 1976). Protein in whole cells was determined after sonication of the cells for $10 \mathrm{~min}$ in the presence of $2 \mathrm{M}-\mathrm{NaOH}$.

Inactivation with $\mathrm{NaBH}_{4}$. Purified 3-dehydroquinate dehydratase was incubated for $40 \mathrm{~min}$ at room temperature with $50 \mathrm{mM}-\mathrm{NaBH}_{4}$ in the presence or absence of 3-dehydroquinate. The incubation mixture contained: $1.0 \mathrm{U}$ 3-dehydroquinate dehydratase, $1.0 \mathrm{mM}$-3-dehydroquinate, $50 \mathrm{~mm}$-Tris/ $/ \mathrm{HCl}$, $\mathrm{pH} 8.5$, and $50 \mathrm{mM}^{-\mathrm{NaBH}_{4}}$ (from a $1.0 \mathrm{M}$ stock solution in $50 \mathrm{mM}-\mathrm{NaOH}$ ) in a total volume of $1.0 \mathrm{ml}$. After 40 min the reaction mixture was diluted to $2.5 \mathrm{ml}$ and immediately transferred onto a Pharmacia PD 10 desalting column; elution was with $3.5 \mathrm{ml} 50 \mathrm{~mm}$-Tris $/ \mathrm{HCl}, \mathrm{pH} 8.5$. In a control experiment $50 \mathrm{~mm}-$ $\mathrm{NaBH}_{4}$ was omitted and only $2.5 \mathrm{~mm}-\mathrm{NaOH}$ was added.

Inhibition studies with aromatic amino acids on purified 3-dehydroquinate dehydratase. Aromatic amino acids were added separately or in combinations to a final concentration of $0.1 \mathrm{mM}$ to the reaction mixture. 3-Dehydroquinate was added to a final concentration of 250 $\mu \mathrm{M}$.

Chemicals. An A. methanolica strain WV2 mutant lacking 3dehydroquinate synthase was found to accumulate DAHP intracellularly. Following preparation of cell-free extracts protein was precipitated with $5 \%(\mathrm{w} / \mathrm{v})$ perchloric acid and the neutralized supernatant used directly as a source of DAHP for enzyme assays. The concentration of DAHP in the solution was determined enzymically, using dehydroquinate synthase, dehydroquinate dehydratase and

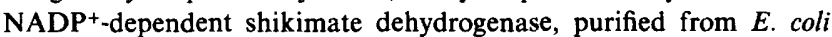
(Coggins et al., 1987). 3-Dehydroquinate was synthesized from Dquinate (Grewe \& Haendier, 1968). 3-Dehydroshikimate was prepared enzymically from 3-dehydroquinate (Coggins et al., 1987). Shikimate, protocatechuate and L-phenylalanine were purchased from Sigma. Quinate was obtained from Janssen Chimica, Belgium. NAD ${ }^{+}$, $\mathrm{NADP}^{+}, \mathrm{L}$-tyrosine and L-tryptophan were obtained from Boehringer. $\mathrm{NaBH}_{4}$ was obtained from Merck. Other chemicals were obtained from local industries.

\section{Results and Discussion}

\section{Quinate and shikimate metabolism}

The doubling time of $A$. methanolica strain WV2 in mineral medium with quinate as sole source of carbon and energy was $3.0 \mathrm{~h}$. Quinate-grown cells were able to oxidize quinate, shikimate, 3-dehydroquinate, 3-dehydroshikimate and protocatechuate (Table 1). Growth on
Table 1. Oxygen consumption rates of glucose- and quinategrown cells of $A$. methanolica strain WV2

Activities are expressed in $\mathrm{nmol} \mathrm{O}_{2} \mathrm{~min}^{-1}\left(\mathrm{mg}\right.$ protein) ${ }^{-1}$.

\begin{tabular}{lcc}
\hline \hline \multirow{2}{*}{ Substrate } & \multicolumn{2}{c}{ Cells grown on: } \\
\cline { 2 - 3 } & Glucose & Quinate \\
\hline Glucose & 170 & 30 \\
Quinate & 20 & 420 \\
3-Dehydroquinate & 0 & 295 \\
3-Dehydroshikimate & 0 & 300 \\
Shikimate & 45 & 305 \\
Protocatechuate & 0 & 170 \\
\hline \hline
\end{tabular}

Table 2. Enzyme activities in crude extracts of glucose- and quinate-grown cells of $A$. methanolica strain $W V 2$

Activities are expressed in $\mathrm{nmol} \mathrm{min}^{-1}$ (mg protein) ${ }^{-1}$. ND, Not detectable.

\begin{tabular}{|c|c|c|}
\hline \multirow[b]{2}{*}{ Enzyme } & \multicolumn{2}{|c|}{ Cells grown on: } \\
\hline & Glucose & Quinate \\
\hline Quinate dehydrogenase (NAD $\left.{ }^{+}\right)$ & 0 & 220 \\
\hline Shikimate dehydrogenase $\left(\mathrm{NAD}^{+}\right)$ & 0 & 175 \\
\hline 3-Dehydroquinate dehydratase & 205 & 210 \\
\hline 3-Dehydroshikimate dehydratase & ND & ND \\
\hline Protocatechuate dioxygenase & 0 & 170 \\
\hline Shikimate dehydrogenase (NADP ${ }^{+}$) & 25 & 30 \\
\hline
\end{tabular}

shikimate alone was not observed; also, addition of $10 \mathrm{~mm}$-shikimate to cells growing on quinate did not result in increased final optical densities. Transfer of glucose-grown cells into a medium with quinate resulted in induction of quinate and shikimate dehydrogenase (both $\mathrm{NAD}^{+}$-dependent) as well as protocatechuate dioxygenase activities while the $\mathrm{NADP}^{+}$-dependent shikimate dehydrogenase appeared to be constitutive (Table 2). Mono $Q$ anion-exchange chromatography failed to resolve the $\mathrm{NAD}^{+}$-dependent quinate- and shikimate dehydrogenases although they were separated from the $\mathrm{NADP}^{+}$-dependent shikimate dehydrogenase (Fig. 2). Addition of shikimate or quinate to $\mathrm{NAD}^{+-}$ dependent quinate dehydrogenase or shikimate dehydrogenase assay systems, respectively, did not result in enhanced activities. Non-denaturating PAGE of extracts, followed by tetrazolium-dependent staining for $\mathrm{NAD}^{+}$-dependent quinate- and shikimate dehydrogenase activities invariably resulted in appearance of a single, identical band with both quinate and shikimate. Taken together, the above data suggest that a single $\mathrm{NAD}^{+}$-dependent quinate/shikimate dehydrogenase is present in $\boldsymbol{A}$. methanolica, as has been described for $N$. crassa (Barea \& Giles, 1978), A. niger (Cain, 1972b) and Rhodococcus rhodochrous (Bruce \& Cain, 1990). The 

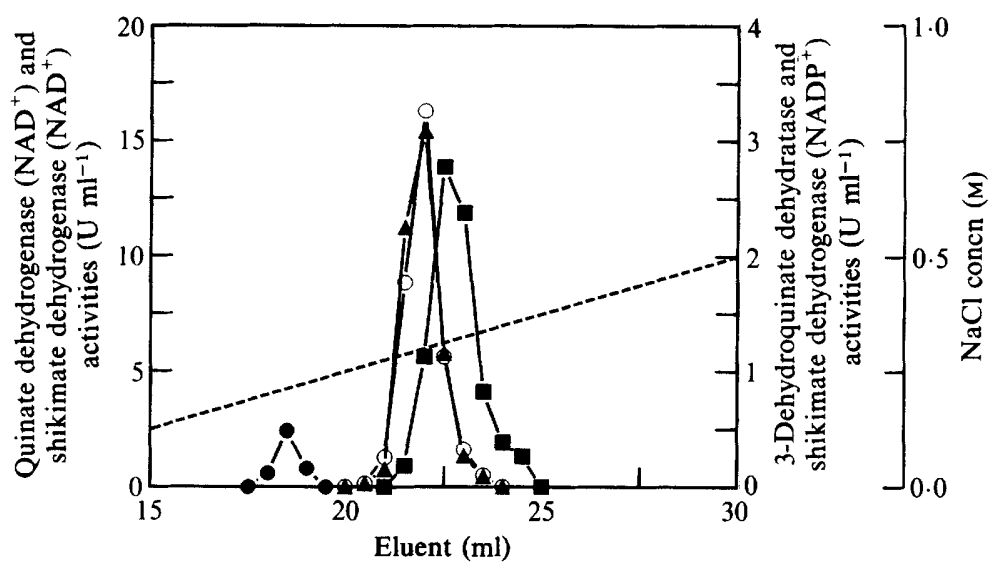

Fig. 2. Mono $Q$ anion-exchange chromatography of crude extract of quinate-grown cells of $A$. methanolica strain WV2. Activity profiles of NAD+-dependent quinate dehydrogenase $(\boldsymbol{A}), \mathrm{NAD}^{+}$-dependent shikimate dehydrogenase $(O)$, 3-dehydroquinate dehydratase ( $\square$ ) and $\mathrm{NADP}^{+}$-dependent shikimate dehydrogenase (O). ---, $\mathrm{NaCl}$ gradient.

Table 3. Enzyme activities in crude extracts of three shikimate-utilizing mutants of A. methanolica strain WV2 grown on glucose or shikimate

Activities are expressed in $\mathrm{nmol} \mathrm{min}^{-1}$ (mg protein) $)^{-1}$.

\begin{tabular}{llcccc}
\hline \hline & $\begin{array}{c}\text { Carbon } \\
\text { source } \\
(10 \mathrm{mM})\end{array}$ & $\begin{array}{c}\text { Shikimate } \\
\text { dehydrogenase } \\
\left(\text { NAD }^{+}\right)\end{array}$ & $\begin{array}{c}\text { Quinate } \\
\text { dehydrogenase } \\
\left(\text { NAD }^{+}\right)\end{array}$ & $\begin{array}{c}\text { Protocatechuate- } \\
\text { 3,4-dioxygenase }\end{array}$ & $\begin{array}{c}\text { Shikimate } \\
\text { dehydrogenase } \\
\left.\text { (NADP }^{+}\right)\end{array}$ \\
\hline S3 & Glucose & 255 & 270 & 0 & 30 \\
S5 & Glucose & 315 & 165 & 0 & 30 \\
S6 & Glucose & 220 & 170 & 0 & 30 \\
S3 & Shikimate & 225 & 235 & 110 & 40 \\
S5 & Shikimate & 280 & 370 & 150 & 35 \\
S6 & Shikimate & 435 & 390 & 150 & \\
\hline \hline
\end{tabular}

Table 4. Purification of 3-dehydroquinate dehydratase from glucose-grown cells of A. methanolica strain $W V 2$

\begin{tabular}{|c|c|c|c|c|c|}
\hline & $\begin{array}{l}\text { Protein } \\
\text { (mg) }\end{array}$ & $\begin{array}{c}\text { Specific } \\
\text { activity } \\
{\left[\mathrm{U}(\mathrm{mg} \text { protein })^{-1}\right]}\end{array}$ & $\begin{array}{l}\text { Total } \\
\text { activity } \\
\text { (U) }\end{array}$ & $\begin{array}{c}\text { Purification } \\
\text { factor } \\
\text { (-fold) }\end{array}$ & $\begin{array}{c}\text { Yield } \\
(\%)\end{array}$ \\
\hline 1. Crude extract & 1426 & $0 \cdot 70$ & 997 & 1 & 100 \\
\hline 2. $40-60 \%\left(\mathrm{NH}_{4}\right)_{2} \mathrm{SO}_{4}$ & 1037 & 0.67 & 696 & 1 & 70 \\
\hline 3. $70^{\circ} \mathrm{C}$ & 237.8 & 2.45 & 583 & 4 & 59 \\
\hline 4. Q-Sepharose & $26 \cdot 2$ & $17 \cdot 1$ & 449 & 25 & 45 \\
\hline 5. Mono $Q$ & 8.08 & $39 \cdot 2$ & 317 & 56 & 32 \\
\hline 6. Phenyl-Superose & 0.728 & 359 & 262 & 514 & 26 \\
\hline 7. $70^{\circ} \mathrm{C}$ & 0.578 & 437 & 253 & 626 & 25 \\
\hline 8. Superose 12 & 0.416 & 533 & 222 & 763 & 22 \\
\hline 9. Mono $Q$ & 0.155 & 1200 & 186 & 1717 & 19 \\
\hline
\end{tabular}

enzyme is clearly different from the constitutive shikimate dehydrogenase, which is exclusively $\mathrm{NADP}^{+}$ dependent.

Although all enzymes necessary for the breakdown of shikimate are present in quinate-grown cells, no growth of $A$. methanolica on shikimate was observed, apparently because shikimate is unable to induce their synthesis. Shikimate is clearly able to enter the cells because low shikimate-dependent oxygen consumption rates are observed in glucose-grown cells (Table 1).

Shikimate-utilizing mutants of $A$. methanolica strain WV2 were readily isolated following incubation of the organism in shikimate mineral medium. The doubling times of mutant strains S3, S5 and S6 on shikimate were estimated as $2 \cdot 1,3.5$ and $2 \cdot 0 \mathrm{~h}$, respectively. Their further characterization revealed that glucose-grown cells of these three mutants already possessed high $\mathrm{NAD}^{+}$dependent quinate/shikimate dehydrogenase activities, indicating that synthesis of the enzyme had become constitutive (Table 3): Protocatechuate dioxygenase was present in quinate- (Table 2) or shikimate-grown cells only (Table 3), suggesting that 3-dehydroshikimate or protocatechuate itself is the inducer of this enzyme. Addition of shikimate $(10 \mathrm{mM})$ to quinate $(10 \mathrm{~mm})$ 


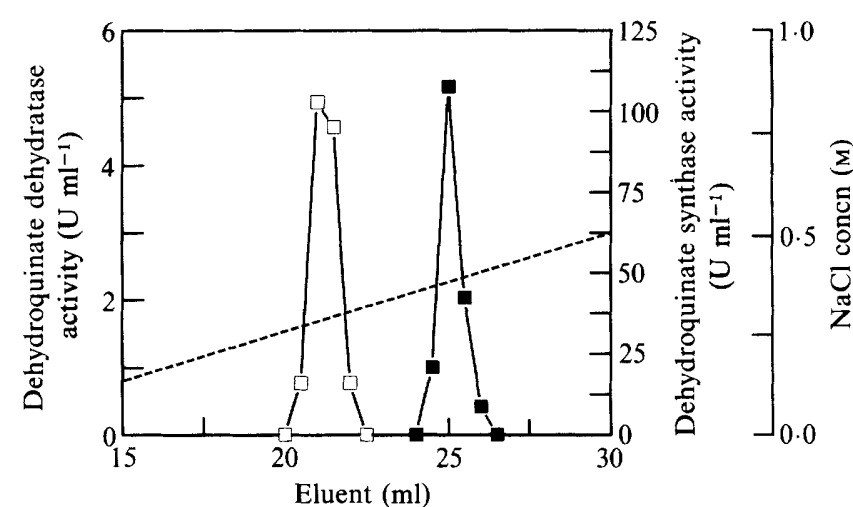

Fig. 3. Mono $Q$ anion-exchange chromatography of crude extract (16.9 mg protein) of glucose-grown cells of $A$. methanolica strain WV2. Specific activities of dehydroquinate synthase and dehydroquinate dehydratase were $8 \mathrm{mU}$ (mg protein) $)^{-1}$ and $203 \mathrm{mU}(\mathrm{mg}$ protein $)^{-1}$ respectively. Activity profiles of 3-dehydroquinate synthase $(\square)$ and 3-dehydroquinate dehydratase $(\mathbf{\square})$ are shown. ---, $\mathrm{NaCl}$ gradient. A yield of over $80 \%$ was obtained. mineral medium now resulted in an approximate doubling of the final cell densities of the mutant strains.

3-Dehydroquinate dehydratase was present at similar activity levels in glucose- and quinate-grown cells of strain WV2 (Table 2). In both cases the enzyme was heat stable and no loss of activity occurred during incubation for at least $10 \mathrm{~min}$ at $70^{\circ} \mathrm{C}$. Interestingly, when glucoseor quinate-grown cells reached the stationary phase, 3dehydroquinate dehydratase became derepressed, resulting in a 3-fold increased specific activity (Table 4). Mono $Q$ anion-exchange chromatography of crude extracts of glucose- or quinate-grown cells revealed only single activity peaks for 3-dehydroquinate dehydratase (Figs 2 and 3). These observations suggest that only a single 3dehydroquinate dehydratase is present in A. methanolica.

3-Dehydroshikimate, the branch-point intermediate (Fig. 1), is converted to either protocatechuate (by 3dehydroshikimate dehydratase) or to shikimate (by $\mathrm{NADP}^{+}$-dependent shikimate dehydrogenase). Although quinate-grown cells clearly oxidized 3-dehydroshikimate (Table 1), 3-dehydroshikimate dehydratase activity was not detected in crude extracts (Table 2) using the assays previously described (Strøman et al., 1978; Bruce \& Cain, 1990). Attempts to measure 3-dehydroshikimate-dependent oxygen consumption in crude extracts, due to the formation of protocatechuate by 3dehydroshikimate dehydratase activity combined with the conversion of protocatechuate by protocatechuate dioxygenase, also failed.

There are indications that in Acinetobacter calcoaceticus 3-dehydroquinate dehydratase and $\mathrm{NADP}^{+}$-dependent shikimate dehydrogenase are present in a loose enzyme complex; this may allow channelling of 3dehydroshikimate to NADP ${ }^{+}$-dependent shikimate dehydrogenase rather than to dehydroshikimate dehydratase (Tresguerres et al., 1972). In plants, these two enzyme activities actually constitute a bifunctional protein with probably the same channelling function (Polley, 1978; Fiedler \& Schultz, 1985; Mousdale et al., 1987). Mono $Q$ anion-exchange chromatography of crude extracts of $A$. methanolica resulted in clear separation of 3-dehydroquinate dehydratase and NADP $^{+}$-dependent shikimate dehydrogenase activities (Fig. 2), although a loose association of these proteins cannot be excluded.

\section{Isolation of mutants defective in 3-dehydroquinate dehydratase}

Amongst a series of several phenylalanine, tyrosine plus tryptophan requiring auxotrophic mutants of $A$. methanolica strain WV2, three isolates (mutant strains GH7, GH12 and GH29) completely lacked both 3-dehydroquinate dehydratase and 3-dehydroquinate synthase activities. Various other isolates (mutant strains GH1, GH3, GH22) were blocked in 3-dehydroquinate synthase only. Mutants with a single block in dehydroquinate dehydratase, however, were not obtained. The data thus indicate that the 3-dehydroquinate synthase and 3dehydroquinate dehydratase genes in A. methanolica are genetically linked; however, their transcription clearly results in the synthesis of two separate proteins (Fig. 3). Such linkage has been reported for the $M$. tuberculosis genes (Garbe et al., 1991). Mutant strains GH7, GH12 and $\mathrm{GH} 29$ were unable to grow on quinate as sole carbon- and energy source, even in media supplemented with all three aromatic amino acids. Mutant strains $\mathrm{GH} 1, \mathrm{GH} 3$ and $\mathrm{GH} 22$ grew normally in quinate mineral medium without requiring supplementation by aromatic amino acids; in glucose medium quinate could replace the three aromatic amino acids as growth supplements. These observations provide further evidence that one and the same 3-dehydroquinate dehydratase enzyme is involved in quinate catabolism and the biosynthesis of aromatic amino acids in $A$. methanolica.

\section{Purification of 3-dehydroquinate dehydratase}

3-Dehydroquinate dehydratase was purified from glucose-grown cells of $A$. methanolica strain WV2 that had 
entered the stationary phase (Table 4). As mentioned above, the specific activity of the enzyme increased considerably in this growth phase, reaching a level of $700 \mathrm{mU}$ (mg protein $)^{-1}$. The heat stability of this 3dehydroquinate dehydratase is quite pronounced (no loss of activity during incubation at $70^{\circ} \mathrm{C}$ for $10 \mathrm{~min}$ ) and simplified its purification (steps 3 and 7). 3-Dehydroquinate dehydratase activity eluted at $300 \mathrm{mM}-\mathrm{NaCl}$ from a Q-Sepharose column. High-resolution anionexchange and hydrophobic interaction chromatography, followed by gel filtration and a second anion-exchange

Table 5. Yield of

phenylthiohydantoin amino acid at each stage of the automated protein sequencing

\begin{tabular}{ccc}
\hline \hline Cycie no. & Residue & $\begin{array}{r}\text { Yield } \\
\text { (pmol) }\end{array}$ \\
\hline 1. & Met & 50 \\
2. & Lys & 23 \\
3. & Val & 40 \\
4. & Phe & 49 \\
5. & Val & 46 \\
6. & Leu & 45 \\
7. & Asn & 38 \\
8. & Gly & 35 \\
9. & Pro & 27 \\
10. & Asn & 25 \\
11. & Leu & 24 \\
12. & Gly & 22 \\
13. & Arg & 13 \\
14. & Leu & 23 \\
15. & Gly & 22 \\
16. & Lys & 6 \\
17. & Arg & 12 \\
18. & Glu & 16 \\
19. & Pro & 13 \\
20. & Ala & 13 \\
\hline \hline
\end{tabular}

chromatography step subsequently were necessary to obtain a pure protein. The use of phosphate ions instead of chloride ions in step 5 resulted in a better resolution of protein peaks in this particular case. 3-Dehydroquinate dehydratase was purified 1717-fold with a total yield of $19 \%$, yielding a homogeneous preparation as judged by SDS-PAGE (Table 4).

\section{Properties of 3-dehydroquinate dehydratase}

The $M_{\mathrm{r}}$ of the native enzyme was estimated as $135 \times$ $10^{3} \pm 12 \times 10^{3}$. SDS-PAGE analysis revealed the presence of a single subunit with an $M_{\mathrm{r}}$ of $12 \times 10^{3}$, indicating a dodecameric quaternary structure for the enzyme. The optimum conditions for 3-dehydroquinate dehydratase activity were found to be $76^{\circ} \mathrm{C}$ and $\mathrm{pH} 9 \cdot 0$. The $K_{\mathrm{m}}$ values of the enzyme for 3-dehydroquinate were $121 \pm 5 \mu \mathrm{M}$ at $\mathrm{pH} 7.5$ and $266 \pm 12 \mu \mathrm{M}$ at $\mathrm{pH} 8.5$. The estimated $V_{\max }$ values were $690 \mathrm{U}$ (mg protein) ${ }^{-1}$ at $\mathrm{pH} 7.5$ and $1607 \mathrm{U}$ (mg protein) ${ }^{-1}$ at $\mathrm{pH} \mathrm{8.5}$. The enzyme was not inhibited by $0.1 \mathrm{mM}$-L-tryptophan, -L-tyrosine or -L-phenylalanine, nor by combinations of these three amino acids.

Type I 3-dehydroquinate dehydratases are irreversibly inactivated during incubation with $\mathrm{NaBH}_{4}$ and 3dehydroquinate because the imine intermediate involved in catalysis is reduced to a stable secondary amine (Chaudhuri et al., 1991; Kleanthous et al., 1992). Type II enzymes, including the biosynthetic dehydroquinate dehydratase of $S$. coelicolor, are not inhibited by this treatment since imine formation does not appear to be involved in the reaction mechanism (Kleanthous et al., 1992). The $A$. methanolica enzyme turned out to be insensitive to $\mathrm{NaBH}_{4}$, in the presence or absence of 3dehydroquinate.

Table 6. Properties and function(s) of 3-dehydroquinate dehydratases from various organisms

\begin{tabular}{|c|c|c|c|c|c|c|}
\hline Enzyme & Organism & $\begin{array}{c}K_{\mathrm{m}} \\
(\mu \mathrm{M})\end{array}$ & $\begin{array}{c}\text { Subunit } \\
M_{\mathrm{r}} \\
\left(\times 10^{-3}\right)\end{array}$ & Structure & Function & Reference \\
\hline Type I & $\begin{array}{l}\text { Escherichia coli } \\
\text { Neurospora crassa } \\
\text { Aspergillus nidulans } \\
\text { Plants }\end{array}$ & $\begin{array}{r}18 \\
5 \\
- \\
27\end{array}$ & $\begin{array}{l}29 \\
165^{*} \\
171^{*} \\
59 \dagger\end{array}$ & $\begin{array}{l}\text { Dimer } \\
\text { Dimer } \\
\text { Dimer } \\
\text { Monomer }\end{array}$ & $\begin{array}{l}\text { Biosynthetic } \\
\text { Biosynthetic } \\
\text { Biosynthetic } \\
\text { Biosynthetic }\end{array}$ & $\begin{array}{l}\text { Chaudhuri et al. (1986) } \\
\text { Coggins et al. }(1987) \\
\text { Charles et al. }(1986) \\
\text { Mousdale } \text { et al. }(1987)\end{array}$ \\
\hline Type II & $\begin{array}{l}\text { Neurospora crassa } \\
\text { Aspergillus nidulans } \\
\text { Streptomyces coelicolor } \\
\text { Mycobacterium tuberculosis } \\
\text { Amycolatopsis methanolica }\end{array}$ & $\begin{array}{r}70 \\
150 \\
650 \\
- \\
121 \S\end{array}$ & $\begin{array}{l}18 \cdot 5 \\
16 \cdot 5 \\
16 \\
14 \ddagger \\
12\end{array}$ & $\begin{array}{l}\text { Dodecamer } \\
\text { Dodecamer } \\
\text { Dodecamer } \\
\text { Dodecamer } \ddagger \\
\text { Dodecamer }\end{array}$ & $\begin{array}{l}\text { Catabolic } \\
\text { Catabolic } \\
\text { Biosynthetic } \\
\text { Biosynthetic } \\
\text { Biosynthetic/ } \\
\text { catabolic }\end{array}$ & $\begin{array}{l}\text { Hautala et al. (1975) } \\
\text { Kleanthous } \text { et al. (1992) } \\
\text { White et al. (1990) } \\
\text { Garbe } \text { et al. (1991) }\end{array}$ \\
\hline
\end{tabular}

* Part of the AROM complex.

† Part of the 3-dehydroquinate dehydratase/NADP+-dependent shikimate dehydrogenase bifunctional enzyme.

$\ddagger$ Personal communication from A. R. Hawkins.

$\S$ Determined at $\mathrm{pH} 7.5$ and $37^{\circ} \mathrm{C}$. 


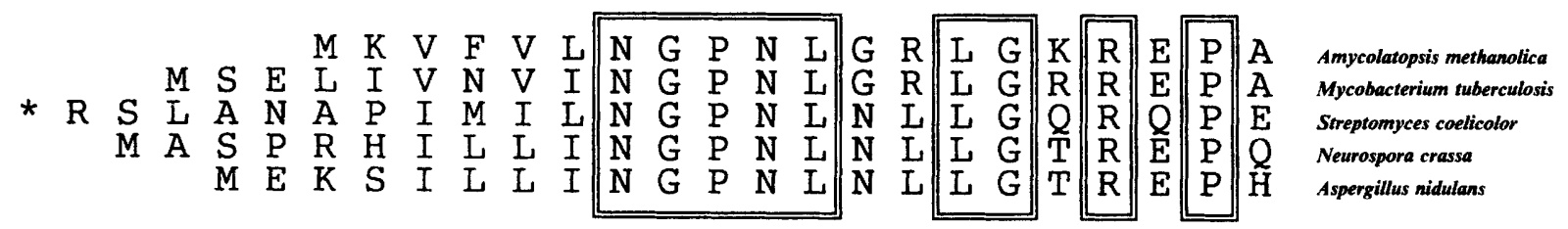

Fig. 4. Alignment of the $\mathrm{N}$-terminal sequences of Type II 3-dehydroquinate dehydratases purified from various organisms. ${ }^{*}$ Not identified.

$\mathrm{N}$-Terminal amino acid sequence analysis initially allowed unambiguous identification of the first eight residues only; in a second experiment (results shown in Table 5) this sequence was confirmed and extended to 20 residues. No homology was found with the Type I biosynthetic 3-dehydroquinate dehydratase from $E$. coli (Duncan et al., 1986). Instead, alignment of the first 20 $\mathrm{N}$-terminal amino acids of the 3-dehydroquinate dehydratase from $A$. methanolica with previously published sequences from Type II enzymes revealed $45 \%$ overall identity with the catabolic enzymes from $N$. crassa (Hawkins et al., 1982) and $A$. nidulans (Da Silva et al., 1986) and the biosynthetic enzymes from $S$. coelicolor (White et al., 1990) and M. tuberculosis (Garbe et al., 1991) (Fig. 4). Highest homology was observed with the $M$. tuberculosis enzyme ( $75 \%$ identity). Compared to the Type I $E$. coli enzyme, all five Type II enzymes have small subunits, are thermostable and have high $K_{\mathrm{m}}$ values for 3-dehydroquinate (Table 6). Amongst these Type II enzymes the $A$. methanolica 3 -dehydroquinate dehydratase is somewhat unusual in its relatively low subunit $M_{\mathrm{r}}$, its intermediate $K_{\mathrm{m}}$ value, and its dual function in both quinate catabolism and the biosynthetic shikimate pathway.

This study was supported by grant no. GBI81.1510 from the Netherlands Technology Foundation (STW) which is subsidised by the Netherlands Organization for the Advancement of Pure Research (NWO).

J. R. Coggins is supported by the UK Science and Engineering Research Council. We thank Mr Brian Dunbar, SERC Protein Sequencing Unit, University of Aberdeen and Dr M. Cusack, Department of Pure and Applied Geology, University of Glasgow for protein sequence determination.

\section{References}

Barea, J. L. \& Giles, N. H. (1978). Purification and characterization of quinate (shikimate) dehydrogenase, an enzyme in the inducible quinic acid catabolic pathway of Neurospora crassa. Biochimica et Biophysica Acta 524, 1-14.

DE BOER, L., HARder, W. \& Dijkhuizen, L. (1988). Phenylalanine and tyrosine metabolism in the facultative methylotroph Nocardia sp. 239. Archives of Microbiology 149, 459-465.

DE Boer, L., VRijbloed, J. W., Grobben, G. \& Dijkhuizen, L. (1989). Regulation of aromatic amino acid biosynthesis in the ribulose monophosphate cycle methylotroph Nocardia sp. 239. Archives of Microbiology 151, 319-325. de Boer, L., Dijkhuizen, L., Grobben, G., Goodfellow, M., Stackebrandt, E., Parlett, J. H., Whitehead, D. \& Witt, D. (1990). Amycolatopsis methanolica sp. nov., a facultatively methylotrophic actinomycete. International Journal of Systematic Bacteriology 40, 194-204.

BradFord, M. M. (1976). A rapid and sensitive method for the quantitation of microgram quantities of protein utilizing the principle of protein-dye binding. Analytical Biochemistry 72, 248254.

BRuCE, N. C. \& CAIN, R. B. (1990). Hydroaromatic metabolism in Rhodococcus rhodochrous: purification and characterization of its NAD-dependent quinate dehydrogenase. Archives of Microbiology 154, 179-186.

CAIN, R. B. (1972a). Metabolism of shikimate and quinate by Aspergillus niger and its regulation. Proceedings of the Biochemical Society $15 \mathrm{p}-16 \mathrm{p}$.

CAIN, R. B. $(1972 b)$. The identity of shikimate dehydrogenase and quinate dehydrogenase in Aspergillus niger. Proceedings of the Biochemical Society $15 \mathrm{p}$.

CAIN, R. B. (1981). Regulation of aromatic and hydroaromatic catabolic pathways in nocardiaform actinomycetes. In Actinomycetes. Proceedings of the Fourth International Symposium on Actinomycete Biology, pp. 335-354. Edited by K. P. Schaal \& G. Pulverer. New York: Gustav Fischer.

ChalefF, R. S. (1974). The inducible quinate-shikimate catabolic pathway in Neurospora crassa: induction and regulation of enzyme synthesis. Journal of General Microbiology 81, 357-372.

Charles, I. G., Keyte, J. W., Brammar, W. J. \& Hawkins, A. R. (1985). Nucleotide sequence encoding the biosynthetic dehydroquinase function of the pentafunctional $A R O M$ locus of Aspergillus nidulans. Nucleic Acids Research 13, 8119-8128.

Charles, I. G., Keyte, J. W., Brammar, W. J., Smith, M. \& Hawkins, A. R. (1986). The isolation and nucleotide sequence of the complex AROM locus of Aspergillus nidulans. Nucleic Acids Research 14, 22012213.

Chaudhuri, S., Lambert, J. M., McColl, L. A. \& Coggins, J. R. (1986). Purification and characterization of 3-dehydroquinase from Escherichia coli. Biochemical Journal 239, 699-704.

Chaudhuri, S., Anton, I. A. \& Coggins, J. R. (1987a). Shikimate dehydrogenase from Escherichia coli. Methods of Enzymology 142, 315-320.

Chaudhuri, S., Duncan, K. \& Coggins, J. R. (1987b). 3-Dehydroquinate dehydratase from Escherichia coli. Methods of Enzymology 142, 320-324.

Chaudhuri, S., Duncan, K., Graham, L. D. \& Coggins, J. R. (1991). Identification of the active-site lysine residues of two biosynthetic 3dehydroquinases. Biochemical Journal 275, 1-6.

Coggins, J. R., Boocock, M. R., Chaudhuri, S., Lambert, J. M., Lumsden, J., Nimmo, G. A. \& Smith, D. D. S. (1987). The arom multifunctional enzyme from Neurospora crassa. Methods of Enzymo$\log y 142,325-341$.

da Silva, A. J. S., Whittington, H., Clements, J., Roberts, C. F. \& HAWKINS, A. R. (1986). Sequence analysis and transformation by the catabolic 3-dehydroquinase (QUTE) gene from Aspergillus nidulans. Biochemical Journal 240, 481-488.

Duncan, K., Chaudhuri, S., Campbell, M. S. \& Coggins, J. R. (1986). The overexpression and complete amino acid sequence of Escherichia coli 3-dehydroquinase. Biochemical Journal 238, 475483.

Fiedler, E. \& SchUlTZ, G. (1985). Localization, purification, and characterization of shikimate oxidoreductase-dehydroquinate 
hydrolyase from stroma of spinach chloroplasts. Plant Physiology 79, $212-218$

Garbe, T., Servos, S., Hawkins, A., Dimitriadis, G., Young, D., Dougan, G. \& Charles, I. G. (1991). The Mycobacterium tuberculosis shikimate pathway genes: evolutionary relationship between biosynthetic and catabolic 3-dehydroquinases. Molecular and General Genetics 228, 385-392.

Giles, N. H., Partridge, C. W. H., Ahmed, S. I. \& Case, M. E. (1967). The occurrence of two dehydroquinases in Neurospora crassa, one constitutive and one inducible. Genetics 58, 1930-1937.

Giles, N. H., Case, M. E., Baum, J., Geever, R., Huiet, L., Patel, V. \& TYLER, B. (1985). Gene organization and regulation in the qa (quinic acid) gene cluster of Neurospora crassa. Microbiological Reviews 49, 338-358.

Grewe, R. \& HAENDLER, H. (1968). 5-Dehydroquinic acid. Biochemical Preparations 11, 21-26.

GRUND, E., KNORR, C. \& EICHENLAUb, R. (1990). Catabolism of benzoate and monohydroxylated benzoates by Amycolatopsis and Streptomyces spp. Applied and Environmental Microbiology 56, 1459 1464

Hautala, J. A., Jacobson, J. W., Case, M. E. \& Giles, N. H. (1975). Purification and characterization of catabolic dehydroquinase, an enzyme in the inducible quinic acid catabolic pathway of Neurospora crassa. Journal of Biological Chemistry 250, 6008-6014.

Hawkins, A. R., ReINERT, W. R. \& Giles, N. H. (1982). Characterization of Neurospora crassa catabolic dehydroquinase purified from $N$. crassa and Escherichia coli. Biochemical Journal 203, 769-773.

Kleanthous, C., Deka, R., Davis, K., Kelly, S. M., Cooper, A., Harding, S. E., Price, N. C., Hawkins, A. R. \& Coggins, J. R. (1992). A comparison of the enzymological and biophysical properties of two distinct classes of dehydroquinase enzymes. Biochemical Journal 282, 687-695.

VAN KleEF, M. A. G. \& DuINE, J. A. (1988). Bacterial NAD(P)independent quinate dehydrogenase is a quinoprotein. Archives of Microbiology 150, 32-36.

LAEMmLI, U. K. \& FAVRe, K. (1973). Maturation of the head of bacteriophage T4. I. DNA packaging events. Journal of Molecular Biology 80, 575-599.
Lamb, H. K., Hawkins, A. R., Smith, M., Harvey, I. J., Brown, J., TURNER, G. \& ROBERTS, C. F. (1990). Spatial and biological characterization of the complete quinic acid utilization gene cluster in Aspergillus nidulans. Molecular and General Genetics 223, 17-23.

Lamb, H. K., Bagshaw, C. R. \& HaWkins, A. R. (1991). In vivo overproduction of the pentafunctional arom polypeptide in Aspergillus nidulans affects metabolic flux in the quinate pathway. Molecular and General Genetics 227, 187-196.

LAMB, H. K., Van DEN Hombergh, J. P. T. W., Newton, G. H., MOORE, J. D., ROBERTS, C. F. \& HAWkINS, A. R. (1992). Differential flux through the quinate and shikimate pathways. Implications for the channelling hypothesis. Biochemical Journal 284, 181-187.

LUMSDEN, J. \& COGGINS, J. R. (1977). The subunit structure of the arom multienzyme complex of Neurospora crassa: a possible pentafunctional polypeptide chain. Biochemical Journal 161, 599-607.

Matsudaira, P. (1987). Sequence from picomole quantities of proteins electroblotted onto polyvinylidene difluoride membranes. Journal of Biological Chemistry 262, 10035-10038.

Mousdale, D. M., Campbell, M. S. \& Coggins, J. R. (1987). Purification and characterization of bifunctional dehydroquinaseshikimate:NADP oxidoreductase from pea seedlings. Phytochemistry 26, 2665-2670.

Polley, L. D. (1978). Purification and characterization of 3dehydroquinate hydrolase and shikimate oxidoreductase. Evidence for a bifunctional enzyme. Biochimica et Biophysica Acta 526, 259266.

Strøman, P., Reinert, W. R. \& Giles, N. H. (1978). Purification and characterization of 3-dehydroshikimate dehydratase, an enzyme in the inducible quinic acid catabolic pathway of Neurospora crassa. Journal of Biological Chemistry 253, 4593-4598.

Tresguerres, M. E. F., Ingledew, W. M. \& Canovas, J. L. (1972). Potential competition for 5-dehydroshikimate between the aromatic biosynthetic route and the catabolic hydroaromatic pathways. Archives of Microbiology 82, 111-119.

White, P. J., Young, J., Hunter, I. S., Nimmo, H. G. \& Coggins, J. R. (1990). The purification and characterization of 3-dehydroquinase from Streptomyces coelicolor. Biochemical Journal 265, 735-738. 